\title{
ANALISA PERENCANAAN SUMBER DAYA MANUSIA DENGAN METODE WISN PADA PETUGAS REKAM MEDIS RUMAH SAKIT X DI SURAKARTA JAWA TENGAH
}

\author{
Yul Asriati $1^{*}$ \\ 1*Prodi Rekam Medis dan Informasi Kesehatan \\ Fakultas Kesehatan Masyarakat Universitas Veteran Bangun Nusantara \\ email: yulasriati66@gmail.com
}

\begin{abstract}
Hospital $X$ in Surakarta is a referral hospital BPJS, has a high workload seen from the high number of outpatient and inpatient visits in the medical record unit of the registration section. The melting is quite high in June 2017, so it requires HR planning in the registration section to calculate the needs of medical records officers using WISN (Work Load Indicator Staff Need). This research method using a sample is non random sampling, namely sampling type of research that is descriptive with a qualitative approach while the desired research design is phenomelogy. The instruments used include observation guidelines, interview guidelines, notebooks, stopwatch. the sample taken in this study is the medical records officer registration section selected by total sampling, who worked in the outpatient and inpatient registration and IGD as many as 49 people. Observations are made every 10 minutes and the results are recorded. Furthermore, the observations are used to calculate standard workload and allowance standards. The result, based on the analysis of the needs of personnel in the medical record installation at Hospital $X$ in Surakarta, that the need for personnel in the registration unit was fulfilled
\end{abstract}

Keywords: HR Planning, Medical Records, WISN

\begin{abstract}
ABSTRAK
Rumah sakit X di Surakarta merupakan rumah sakit rujukan BPJS, mempunyai beban kerja yang tinggi terlihat dari jumlah kunjungan pasien rawat jalan dan rawat inap di unit rekam medis bagian pendaftaran. lebur yang cukup tinggi yaitu sebanyak 32,5 jam pada bulan September 2017. Sehingga membutuhkan perencanaan SDM di bagian pendaftaran, untuk menghitung kebutuhan petugas rekam medis menggunakan WISN (Work Load Indicator Staff Need). Metode penelitian ini menggunakan sampel yaitu non random sampling. Jenis penelitian yang adalah deskriptif dengan pendekatan kualitatif sedangkan rancangan penelitian yang diinginkan adalah fenomelogi. Instrumen yang digunakan antara lain pedoman observasi, pedoman wawancara, buku catatan, stopwatch. sampel yang diambil dalam penelitian ini adalah petugas rekam medis bagian pendaftaran yang dipilih secara total sampling seluruh petugas rekam medis yang berkerja di bagian pendaftaran rawat jalan dan rawat inap serta IGD sebanyak 49 orang. Pengamatan dilakukan setiap 10 menit dan hasilnya di catat. Selanjutnya hasil pengamatan digunakan untuk menghitung standar beban kerja dan standar kelonggaran. Hasilnya, Berdasarkan analisis kebutuhan tenaga di instalasi rekam medis RS X di Surakarta bahwa kebutuhan tenaga di unit pendaftaran sudah memenuhi
\end{abstract}

Kata Kunci: Perencanaan SDM, Rekam Medis, WISN 


\section{PENDAHULUAN}

Pembangunan di bidang kesehatan merupakan salah satu bagian yang penting dari pembangunan nasional. Tujuan utama dari pembangunan dibidang kesehatan adalah untuk meningkatkan derajat kesehatan masyarakat dengan memberikan pelayanan kesehatan yang lebih luas, merata dan dapat terjangkau, baik oleh mayarakat perkotaan dan perdesaan. Derajat kesehatan yang tinggi, di harapkan akan meningkatkan kualitas sumberdaya manusia. untuk mewujudkan tujuan tersebut rumah sakit merupakan salah satu sarana yang dapat menunjang pembangunan kesehatan daerah khususnya di kabupaten dan kota sangat ditentukan oleh kualitas sumberdaya manusia dan peran aktif masyarakat sebagai pelaku pembangunan tersebut. (Armen \& Azwar. 2013). Fungsi utama rumah sakit adalah menyelenggarakan pelayanana kesehatan yang mengutamakan pelayaanan, pelayanan kesehatan perorangan meliputi pelayanan kesehatan kuratif, rehabilitative secara serasi dan terpadu dengan pelayanan preventif dan promotif. (Kepmenkes no 81/Menkes/SK///2004) Untuk menjalankan tugas tersebut perlu dukungan adanya unit - unit pembantu yang mempunyai tugas spesifik diantaranya unit rekam medis. Unit rekam medis bertanggungjawab terhadap pengelolahan data pasien menjadi informasi kesehatan yang berguna bagi pengambilan keputusan (Budi. 2011) maka di perlukannya penyusunan dalam perencanaan SDM di unit rekam medis.

Keputusan menteri kesehatan nomor 81/MENKES/SK/I/2004 tentang pedoman penyusunan perencanaan sumber daya manusia kesehatan di tingkat propinsi, kabupaten/kota serta rumah sakit menggunakan WISN (work load indicator staff need). WISN adalah indikator yang menunjukan besarnya kebutuhan tenaga pada sarana kesehatan berdasarkan beban kerja, sehingga alokasi/relokasi akan lebih mudah dan rasional.
Keputusan menteri kesehatan nomor 81/MENKES/SK/I/2004 bahwa penyusunan perencanaan sumber daya manusia yaitu tenaga kesehatan menggunakan 5 (lima):

1. Menetapkan waktu kerja tersedia

2. Menetapkan unit kerja dan kategori SDM

3. Menyusun standar beban kerja

4. Menyusun standar kelonggaran

5. Perhitungan kebutuhan tenaga per unit kerja

Data yang dibutuhkan dalam menyusun beban kerja masing - masing kategori unit kerja meliputi :

a. Kegiatan pokok yang dilaksanakan oleh masing - masing kategori. Kegiatan pokok adalah kumpulan berbagai jenis kegiatan sesuai dengan standar pelayanan dan Standar Operasional Prosedur (SOP) untuk menghasilkan pelayanan kesehatan/medik yang dilaksanakan oleh SDM kesehatan kopetensi tertentu

b. Rata - rata waktu yang dibutuhkan untuk menyelesaikan tiap kegiatan pokok. Rata- rata waktu adalah suatu waktu yangdibutuhkan untuk menyelesaikan suatu kegiatan pokok, oleh masing - masing kategori SDM pada tiap unit.

c. Standar beban kerja per 1 tahun masing - masing kategori SDM.

d. Standar beban kerja adalah volume/kuantitas beban kerja selama 1 tahun per kategori SDM. Standar beban kerja untuk suatu kegiatan poko disusun berdasarkan waktu yang dibutuhkan untuk menyelesaikan (waktu rata - rata) dan waktu kerja tersedia yang dimiliki oleh masing masing kategori SDM (Kepmenkes Nomor 81/Menkes/SK/I/2004)

Penyusunan faktor kelonggaran dapat dilaksanakan melalui pengamatan dan wawancara kepada tiap kategori tentang:

a. Kegiatan - kegiatan yang tidak terkait langsung dengan pelayanan pada pasien misalnya; rapat, penyusunan laporan dll. 
b. Frekuensi dalam satu hari, minggu, bulan.

c. Waktu yang dibutuhkan untuk menyelesaikan kegiatan (Kepmenkes Nomor 81/Menkes/SK///2004).

Berdasarkan hasil observasi RS X Surakarta mempunyai 69 tenaga rekam medis serta memiliki 49 orang petugas rekam medis di bagian pendaftaran. Petugas pendaftaran terbagi menjadi tiga shift yaitu shif pagi, siang, malam dan hari libur.

Berdasarkan lebur yang cukup tinggi pada juni tahun 2017. Kondisi tersebut dapat dikatakan bahwa kinerja bagian rekam medis di RS X kurang optimal. Hal ini disebabkan oleh beban kerja yang tinggi Oleh karena itu peneliti ingin menegtahui kebutuhan petugas pendaftaran menggunakan metode WISN.

\section{METODOLOGI PENELITIAN}

Jenis penelitian yang digunakan adalah deskriptif dengan pendekatan kualitatif sedangkan rancangan penelitian yang diinginkan adalah fenomelogi. Metode yang digunakan dalam penentuan sampel adalah non random sampling yaitu pengambilan sampel berdasarkan atas kemungkinan dapat di perhitungkan tetapi didasarkan kepada segi - segi kepraktisan belaka (Notoatmodjo, S. 2012).

Instrumen yang digunakan antara lain pedoman observasi, pedoman wawancara, buku catatan, stopwatch. Sampel yang diambil dalam penelitian ini adalah petugas rekam medis bagian pendaftaran yang dipilih secara total sampling, yang menjadi sample penelitian ini adalah seluruh petugas rekam medis yang berkerja di bagian pendaftaran rawat jalan dan rawat inap serta IGD sebanyak 49 orang. Pengamatan dilakukan setiap 10 menit dan hasilnya di catat. Selanjutnya hasil pengamatan digunakan untuk menghitung standar beban kerja dan standar kelonggaran.

Kriteria inklusi adalah semua kegiatan petugas rekam medis di pendaftaran rawat jalan dan inap serta IGD, sedangkan kriteria eksklusi adalah petugas rekam medis bagian assembling, filling dan aktifitas petugas di luar waktu aktifitas saat pengamatan. Dalam penelitian ini dilakukan prediksi pada tahun 2017 jumlah pasien rawat inap dan rawat jalan serta IGD.

\section{HASIL}

Untuk menghitung kebutuhan SDM rekam medis sub unit kerja pendaftaran pasien rawat inap dan rawat jalan 2018 maka dibutuhkan data jumlah kunjungan pasien tahun 2017 di rawat jalan $=547.909$ orang dan rawat inap $=67.632$ orang.

\section{Menghitung Waktu Kerja Tersedia Setiap SDM Pada Unit Rekam Medis}

Langkah pertama dalam penyusunan WISN menghitung waktu kerja yang tersedia dengan rumus :

\section{$\mathrm{WKT}=[\mathrm{A}-(\mathrm{B}+\mathrm{C}+\mathrm{D}+\mathrm{E})] \times \mathrm{F}$}

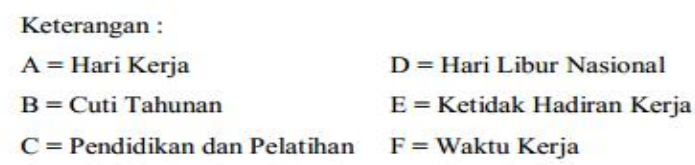

Tabel. 1. Perhitungan Waktu Kerja Tersedia dengan 5 hari kerja Tahun 2018

\begin{tabular}{llrc}
\hline No & \multicolumn{1}{c}{ Faktor } & Jumlah & \multicolumn{1}{c}{ Ket } \\
\hline A & Hari Kerja & 260 & Hari / Tahun \\
B & $\begin{array}{l}\text { Cuti Tahunan } \\
\text { dan cuti } \\
\text { bersama }\end{array}$ & 8 & Hari / Tahun \\
C & $\begin{array}{l}\text { Pendidikan dan } \\
\text { pelatihan }\end{array}$ & 6 & Hari / Tahun \\
D & $\begin{array}{l}\text { Hari libur } \\
\text { nasional }\end{array}$ & 16 & Hari / Tahun \\
E & $\begin{array}{l}\text { Ketidakhadiran } \\
\text { Waktu kerja } \\
\text { efektif }\end{array}$ & 12 & Hari / Tahun \\
& $\begin{array}{l}\text { Waktu kerja } \\
\text { tersedia }\end{array}$ & 1526 & Jam/thari \\
& & 91560 & Menit/tahun \\
\hline & & 5493600 & Detik/tahun \\
\hline
\end{tabular}

Berdasarkan perhitungan pada Tabel 1 diketahui bahwa waktu kerja tersedia yang diperoleh selama satu tahun di Rumah Sakit X adalah 91560 menit per tahun bila dijamkan menjadi 1526 jam/tahun. 
Tabel. 2. Perhitungan Waktu Kerja

Tersedia 7 hari kerja Tahun 2018

\begin{tabular}{llrl}
\hline No & \multicolumn{1}{c}{ Faktor } & Jumlah & \multicolumn{1}{c}{ Ket } \\
\hline A & Hari Kerja & 364 & Hari / Tahun \\
B & $\begin{array}{l}\text { Cuti Tahunan } \\
\text { dan cuti } \\
\text { bersama }\end{array}$ & 8 & Hari / Tahun \\
& $\begin{array}{l}\text { Pendidikan dan } \\
\text { pelatihan }\end{array}$ & 6 & Hari / Tahun \\
D & 16 & Hari / Tahun \\
D & $\begin{array}{l}\text { Hari libur } \\
\text { nasional }\end{array}$ & 12 & Hari / Tahun \\
F & $\begin{array}{l}\text { Ketidakhadiran } \\
\text { Waktu kerja } \\
\text { efektif }\end{array}$ & 7 & Jari \\
& $\begin{array}{l}\text { Waktu kerja } \\
\text { tersedia }\end{array}$ & 2254 & Jam/tahun \\
\hline & & 135240 & Menit/tahun \\
\hline & & 8114400 & Detik/ tahun \\
\hline
\end{tabular}

Berdasarkan perhitungan pada Tabel

1 diketahui bahwa waktu kerja tersedia yang diperoleh selama satu tahun di Rumah Sakit X adalah 135240 menit/tahun bila dijamkan menjadi 2254 jam/tahun.

\section{Menyusun Unit Kerja Di Rekam Medis Bagian Pendaftaran}

Menyusun unit kerja bagian pendaftaran menyusun unit - unit yang dilakukan oleh rekam medis di bagian pendaftaran.

\section{Menyusun Standar Beban Kerja (SBK)}

Dalam menyusun standar beban kerja yang dibutuhkan yaitu

a. Standar beban kerja : volume/kuantitas beban kerja 1 tahun

b. Disusun berdasarkan waktu yang dibutuhkan untuk menyelesaikan (rata-rata waktu) dan waktu yang tersediah/tahun yang dimiliki oleh masih - masing kategori tenaga

Dalam menghitung standar beban kerja menggunakan rumus WISN yakni :

Standar bebankeria $=\frac{\text { Waktukerja tersedia }}{\text { Rata-rata waktuper kegiatan pokok }}$

Didalam standar beban kerja jenis kegiatan sesuai standar pelayanan
\& SPO untuk menghasilkan pelayanan yang dilaksanakan oleh tenaga rekam medis dengan kopetensi tertentu (Siswati. 2018)

\section{Menyusun Standar Kelonggaran (SKG)}

Standar Kelonggaran dapat diperoleh dengan melakukan perhitungan sebagai berikut :

Standar kelonggaran = rata - rata waktu per faktor kelonggaran

Waktu kerja tersedio

Tabel 3. Waktu Kelonggaran untuk 5 hari Petugas Rekam Medis

\begin{tabular}{llrr} 
Faktor & \multicolumn{1}{c}{ Waktu } & WKT & SKG \\
Kelonggaran & 2 jam/ bulan & 1526 & 0,07 \\
Rutin bulanan & 1 jam/hari & 1526 & 0,03 \\
Apel & 1 jam/hari & 1526 & 0,03 \\
Bimbingan PKL & 1 jam/hari & 1526 & 0,03 \\
Laporan & 1 jam/hari & 1526 & 0,03 \\
Rapat & & Total & 0.19
\end{tabular}

Berdasarkan perhitungan pada tabel 3, diperoleh data standar kelonggaran kerja dengan 5 hari kerja adalah 0,19 tenaga.

Tabel 4. Waktu Kelonggaran 7 hari Petugas Rekam Medis

\begin{tabular}{llcr} 
Faktor & Waktu & WKT & SKG \\
Kelonggaran & 2 jam/ bulan & 2254 & 0,05 \\
Rutin bulanan & 1 jam/hari & 2254 & 0,02 \\
Apel & 1 jam/hari & 2254 & 0,02 \\
Bimbingan PKL & & Total & 0,09 \\
\hline
\end{tabular}

Berdasarkan perhitungan pada tabel 4, diperoleh data standar kelonggaran kerja dengan 7 hari kerja adalah 0,09 tenaga.

\section{Perhitungan Kebutuhan Tenaga Kerja Di Unit Pendaftaran Rekam Medis}

Perhitungan kebutuhan SDM per unit kerja bertujuan untuk memperoleh jumlah dan jenis/kategori SDM per unitkerja sesuai dengan beban kerja selama satu tahun. Sumber - sumber data yang dibutuhkan SDM per unit kerja meliputi waktu kerja tersedia, standar beban kerja dan satandar kelonggaran dan kuantitas 
kegiatan pokok tiap unit selama kurun waktu 1 tahun.

Dalam perhitungan kebutuhan tenaga kerja menggunkan rumus perhitungan WISN yakni :

Kebutuhan tenaga kerja $=\underline{\text { kuantitas kegiatan pokok }}+$ standar kelonggaran Standar beban kerja

Hasil perhitungan menunjukkan bahwa kebutuhan SDM tiap-tiap Unit Kerja Rekam Medis (UKRM) pada RS X adalah:

a. Bagian pendaftaran rawat jalan pasien baru dibutuhkan sebanyak 17.64 dibulatkan menjadi 18 orang (Tabel 5).

b. Bagian pendaftaran rawat jalan pasien lama dibutuhkan sebanyak 9.74 dibulatkan menjadi 10 orang (Tabel 6).

c. Bagian pendaftaran IGD pasien baru SDM yang dibutuhkan sebanyak 9.23 dibulatkan menjadi 9 orang (Tabel 7).

d. Bagian pendaftaran IGD pasien lama membutuhkan petugas sebanyak 6.26 dibulatkan menjadi 6 orang (Tabel 8) e. Bagian pendaftaran rawat inap dibutuhkan sebanyak 5.57 dibulatkan menjadi 5 orang (Tabel 9).

Setelah dilakukan perhitungan kebutuhan petugas dengan rumus WISN ternyata tidak diperlukan penambahan jumlah petugas rekam medis bagian pendaftaran berjumlah 49 orang. Rincian perhitungan disajikan pada Tabel 10.

\section{PEMBAHASAN}

Setiap fasilitas pelayanan kesehatan mempunyai kewajiban untuk memberikan pertanggungjawaban atas pelayanan yang telah diberikan (Budi. 2011). Pelayanan rumah sakit yang harus "segar" akan memerlukan peran sumber daya manusia yang handal karena mutu pelayanan akan berada pada pundak mereka. Keberhasilan tergantung pula faktor manusia walaupun dengan bantuan alat, pada saat kritis yang dapat berfikir dan mengambil keputusan adalah manusia yang memiliki kemampuan (Sabarguna\& Sumarni, 2004).

Tabel 5. Perhitungan Kebutuhan SDM Bagian Pendaftaran Rawat Jalan Pasien Baru

\begin{tabular}{|c|c|c|c|c|c|c|c|}
\hline No & Kegiatan & $\begin{array}{l}\text { Waktu rata- } \\
\text { rata (menit) }\end{array}$ & $\begin{array}{l}\text { Waktu } \\
\text { Kerja } \\
\text { Tersedia }\end{array}$ & SBK & SKG & $\begin{array}{c}\text { Kuantitas } \\
\text { volume }\end{array}$ & $\begin{array}{c}\text { SDM } \\
\text { yang } \\
\text { dibutu } \\
\text { h-kan }\end{array}$ \\
\hline 1 & $\begin{array}{l}\text { Wawancara dan pengencekan } \\
\text { persyaratan pasien }\end{array}$ & 0.63 & 91560 & 145333,4 & 0.19 & 287955 & 2.17 \\
\hline 2 & $\begin{array}{l}\text { Menulis nomor antrian } \\
\text { diregrister poliklinik dan karcis } \\
\text { untuk antrian di poliklinik }\end{array}$ & 0.45 & 91560 & 203466,7 & 0.19 & 287955 & 1.60 \\
\hline 3 & $\begin{array}{l}\text { Menulis data pasien di buku } \\
\text { register dan input data ke } \\
\text { computer }\end{array}$ & 1.11 & 91560 & 82486,5 & 0.19 & 287955 & 3.68 \\
\hline 4 & Membuat KIB & 0.35 & 91560 & 261600 & 0.19 & 287955 & 1.29 \\
\hline 5 & Membuat Map baru & 0.70 & 91560 & 64092 & 0.19 & 287955 & 4.68 \\
\hline \multirow[t]{2}{*}{6} & $\begin{array}{l}\text { Menginput data dan mengeprin } \\
\text { SEP }\end{array}$ & 0.78 & 91560 & 71416,8 & 0.19 & 287955 & 4.22 \\
\hline & Total & 4.02 & & 828395,4 & & & 17.64 \\
\hline
\end{tabular}

Table 6. Perhitungan Kebutuhan SDM Bagian Pendaftaran Rawat Jalan Pasien Lama

\begin{tabular}{lccccccc}
\hline No & Kegiatan & $\begin{array}{c}\text { Waktu rata- } \\
\text { rata (menit) }\end{array}$ & $\begin{array}{c}\text { Waktu } \\
\text { kerja } \\
\text { tersedia }\end{array}$ & SBK & SKG & $\begin{array}{c}\text { Kuantitas } \\
\text { /volume }\end{array}$ & $\begin{array}{c}\text { SDM yang } \\
\text { dibutuhkan }\end{array}$ \\
\hline 1 & Memanggil, & 1.10 & 91560 & 83236,3 & 0.19 & 259954 & 3.31
\end{tabular}


mewawancarai dan

memeriksa persyaratan

kelengkapan yang

ditentukan

2 Menulis nomor antrian

di registrasi poliklinik

dan karcis untuk

poliklinik

3 Menuliskan data

pasien di buku register

dan input data ke

komputer

4 Menginput data dan mengeprin SEP Total

Table 7. Perhitungan Kebutuhan SDM Bagian Pendaftaran IGD Pasien Baru

\begin{tabular}{|c|c|c|c|c|c|c|c|}
\hline No & Kegiatan & $\begin{array}{l}\text { Waktu rata- } \\
\text { rata (menit) }\end{array}$ & $\begin{array}{c}\text { Waktu kerja } \\
\text { tersedia }\end{array}$ & SBK & SKG & $\begin{array}{l}\text { Kuantitas } \\
\text { /volume }\end{array}$ & $\begin{array}{l}\text { SDM yang } \\
\text { dibutuhkan }\end{array}$ \\
\hline 1 & $\begin{array}{l}\text { Mewawancarai dan } \\
\text { memeriksa } \\
\text { persyaratan }\end{array}$ & 0.84 & 135240 & 161000 & 0,09 & 287955 & 1.88 \\
\hline 2 & $\begin{array}{l}\text { Menulis data pasien } \\
\text { di buku resgiter dan } \\
\text { input data ke } \\
\text { computer }\end{array}$ & 1.12 & 135240 & 120750 & 0,09 & 287955 & 2.47 \\
\hline 3 & $\begin{array}{l}\text { Membuat KIB dan } \\
\text { status rekam medis }\end{array}$ & 1.74 & 135240 & 77724,1 & 0,09 & 287955 & 3.79 \\
\hline 4 & Membuat SEP & 0.47 & 135240 & 287744.7 & 0,09 & 287955 & 1.09 \\
\hline & Total & 4.17 & & 3237218,8 & & & 9.23 \\
\hline
\end{tabular}

Table 8. Perhitungan Kebutuhan SDM Bagian Pendaftaran IGD Pasien Lama

\begin{tabular}{clrrrrrr}
\hline No & Kegiatan Pokok & $\begin{array}{c}\text { Waktu rata- } \\
\text { rata (menit) }\end{array}$ & $\begin{array}{c}\text { Waktu Kerja } \\
\text { Tersedia }\end{array}$ & SBK & SKG & $\begin{array}{c}\text { Kuantitas } \\
\text { /volume }\end{array}$ & $\begin{array}{c}\text { SDM yang } \\
\text { dibutuhkan }\end{array}$ \\
\hline 1 & $\begin{array}{l}\text { Mewawancarai } \\
\text { dan memeriksa } \\
\text { persyaratan }\end{array}$ & 1.83 & 135240 & 73901,6 & 0,09 & 259954 & 3.60 \\
2 & & & & & & \\
& $\begin{array}{l}\text { Menulis data } \\
\text { pasien di buku } \\
\text { register }\end{array}$ & 0.83 & 135240 & 162939.7 & 0,09 & 259954 & 1.69 \\
3 & Membuat SEP & 0.46 & 135240 & 294000 & 0,09 & 259954 & 0.97 \\
\hline & Total & 3.12 & & 436872.58 & & & 6.26 \\
\hline
\end{tabular}

Table 9. Perhitungan Kebutuhan SDM Bagian Pendaftaran Rawat Inap

\begin{tabular}{ccccccrc}
\hline No & Kegiatan Pokok & $\begin{array}{c}\text { Waktu } \\
\text { rata-rata } \\
\text { (menit) }\end{array}$ & $\begin{array}{c}\text { Waktu } \\
\text { kerja } \\
\text { tersedia }\end{array}$ & SBK & SKG & $\begin{array}{c}\text { Kuantitas } \\
\text { /volume }\end{array}$ & $\begin{array}{c}\text { SDM yang } \\
\text { dibutuhkan }\end{array}$ \\
\hline 1 & $\begin{array}{l}\text { Memewawancarai dan } \\
\text { memeriksa acc rawat }\end{array}$ & 1.40 & 135240 & 96600 & 0,09 & 67632 & 0.79
\end{tabular}




\begin{tabular}{|c|c|c|c|c|c|c|c|}
\hline & $\begin{array}{l}\text { inap acc rawat inap oleh } \\
\text { dokter yang memeriksa }\end{array}$ & & & & & & \\
\hline 2 & $\begin{array}{l}\text { Menulis data pasien di } \\
\text { buku register dan input } \\
\text { data ke computer }\end{array}$ & 2.16 & 135240 & 62611.1 & 0,09 & 67632 & 1.08 \\
\hline 3 & $\begin{array}{l}\text { Petugas mengambil } \\
\text { berkas rekam medis } \\
\text { pasien }\end{array}$ & 1.20 & 135240 & 112700 & 0,09 & 67632 & 0.69 \\
\hline 4 & $\begin{array}{l}\text { Petugas mengisi lembar } \\
\text { persetujuan, pernyataan, } \\
\text { tatib rumah sakit dengan } \\
\text { dibubuhi tanda tangan } \\
\text { petugas dan } \\
\text { pasien/keluarga }\end{array}$ & 2.50 & 135240 & 54096 & 0,09 & 67632 & 1.34 \\
\hline 5 & Membuat SEP & 1.23 & 135240 & 109951.2 & 0,09 & 67632 & 0.71 \\
\hline 6 & $\begin{array}{l}\text { Petugas membuat gelang } \\
\text { pasien }\end{array}$ & 0.79 & 135240 & 171189.8 & 0,09 & 67632 & 0.49 \\
\hline \multirow[t]{2}{*}{7} & Petugas mencetak label & 0.75 & 135240 & 180320 & 0,09 & 67632 & 0.47 \\
\hline & Total & 10.03 & & 648071.66 & & & 5.57 \\
\hline
\end{tabular}

Tabel 10. Hasil Perhitungan Kebutuhan Tenaga Rekam Medis

\begin{tabular}{clrr}
\hline No & \multicolumn{1}{c}{ Sub unit kerja } & Hasil perhitunngan SDM (Orang) & Hasil Pembulatan \\
\hline 1 & Pendaftaran rawat jalan pasien baru & 17.64 & 18 \\
2 & Pendaftaran rawat jalan pasien lama & 9.74 & 10 \\
3 & Pendaftaran UGD pasien baru & 9.23 & 9 \\
4 & Pendaftaran IGD Pasien lama & 6.26 & 6 \\
5 & Pendaftaran rawat inap & 5.57 & 6 \\
\hline & Total & & 49 \\
\hline
\end{tabular}

Maka dari itu perlunya pengelolahan SDM Kesehatan khususnya perencanaan SDM kesehatan, perencanaan SDM selama ini bersifat administratif kepegawaian dan belum dikelolah secara professional, masih bersifat top down dari pusat, belum bottom up (dari bawah), belum sesuai kebutuhan organisasi dan kebutuhan nyata di lapangan, serta belum berorientasi pada jangka panjang (KEPMENKES no 81/MENKES/SK/I/2004). Tujuan dari perencanaan SDM sendiri salah satunya untuk menghindari terjadinya missmanagement dan tumpang tindih dalam pelaksanaan tugas serta untuk menjamin tersedianya tenaga kerja di masa kini maupun masa depan, sehingga setiap pekerjaan ada yang mengerjakan (Rivai \& Sagala. 2009).

Salah satunya yaitu pembuatan informasi kesehatan yaitu rekam medis. Unit rekam medis sebagai salah satu gerbang terdepan dalam pelayanan kesehatan, dapat sebagai salah satu ukuran kepuasan pasien dalam menerima pelayanan (Budi. 2011). Untuk itu diperlukan pengelolahan SDM dibidang kesehatan.

Menurut Peraturan Menteri Dalam Negeri No 12 Tahun 2008 Tentang Pedoman Analisis Beban Kerja Di Lingkungan Departemen Dalam Negeri dan Pemerintahan Daerah, analisis beban kerja dilaksanakan untuk mengukur dan menghitung beban kerja setiap jabatan atau unit kerja dalam rangka efisiensi dan efektivitas pelaksanaaan tugas dan meningkatkan kapasitas organisasi yang profesionalitas, trasnparan, proposional dan rational.

Salah satu cara untuk mengatasi adanya penumpukan dalam beban kerja rekam medis adalah dengan pembagian tugas dalam pendaftaran. Hal ini terlihat bahwa penumpukan beban kerja hanya saat-saat tertentu. Adanya penambahan petugas di shif rawat jalan akan meringankan beban kerja petugas rekam medis. Selain itu perlu adanya roling petugas bagian pendaftaran di rawat jalan, rawat inap, IGD agar kecukupan tugas bagian setiap unit pendaftaran terpenuhi. 
Cara lain adalah dengan membuat diagram fish bone menguraikan permasalahan yang ada di dalam unit rekam medis agar terpecahkan dengan adanya diagram tersebut.

\section{KESIMPULAN}

Berdasarkan analisis jumlah kebutuhan tenaga bagian pendaftaran di instalasi rekam medis RS X Surakarta dapat diambil kesimpulan bahwa kebutuhan tenaga tiap kategori SDM di pendaftaran Intalasi rekam medis untuk tahun 2018 sudah sesuai dengan beban kerja yang ada di bagian pendaftaran unit kerja rekam medis rumah sakit X Surakarta.

\section{DAFTAR PUSTAKA}

Armen F, \& Azwar V. 2013. Dasar - dasar manajemen keuangan rumah sakit. Gosyen Publishing. Yogyakarta.

Budi, Savitri C. 2011. Manajemen unit kerja rekam medis. Yogyakarta : Quantum Sinergis Media

Keputusan menteri kesehatan nomor 81/MENKES/SK/I/2004 tentang pedoman penyusunan perencanaan sumber daya manusia kesehatan di tingkat propinsi, kabupaten/kota serta rumah sakit

Notoatmodjo, Soekidjo. 2012. Metodologi Penelitian Kesehatan. Rineka cipta. Jakarta.

Peraturan Menteri Dalam Negeri No 12 .2008. Pedoman Analisis Beban Kerja Di Lingkungan Departemen Dalam Negeri dan Pemerintahan Daerah,

Rivai, V. dan E.J, Sagala. 2009. Manajemen Sumber Daya Manusia Untuk Perusahaan: Dari Teori ke Praktik. PT Rajagrafindo Persada. Jakarta.

Sabarguna, B. S. dan Sumarni. 2004. Sumber Daya Manusia Rumah Sakit.
Yogyakarta: Konsorsium Rumah Sakit Islam Jateng

Siswati. 2018. Manajemen Unit Kerja II Perencanaan SDM Unit Kerja Rekam Medis. Pusat Pendidikan SDM Kesehatan Badan Pengembangan Dan Pemberdayaan SDMK. Kementrian Kesehatan Republik Indonesia. Jakarta 